\title{
Systematic revision of the enigmatic Malagasy broad-headed frogs (Laurentomantis Dubois, 1980), and their phylogenetic position within the endemic mantellid radiation of Madagascar
}

\author{
Miguel Vences ${ }^{1}$, Frank Glaw ${ }^{2}$, Franco Andreone ${ }^{3}$, Riccardo Jesu ${ }^{4}$ \& Giovanni Schimmenti ${ }^{4}$ \\ 'Muséum national d'Histoire naturelle, Laboratoire des Reptiles et Amphibiens, 25 rue Cuvier, 75005 Paris, \\ France; address for correspondence: Zoologisches Forschungsinstitut und Museum Alexander Koenig, \\ Adenauerallee 160, 53113 Bonn, Germany; email: m.vences@t-online.de; ${ }^{2} Z o o l o g i s c h e ~ S t a a t s s a m m l u n g$, \\ Münchhausenstr. 21, 81247 München, Germany; e-mail: Frank.Glaw@zsm.mwn.de; ${ }^{3}$ Museo Regionale \\ di Scienze Naturali, Sezione di Zoologia, Via G. Giolitti, 36, 10123, Torino, Italy; \\ email: frandreone@libero.it; ${ }^{4}$ Acquario di Genova, Area Porto Antico, Ponte Spinola, 16128 Genova, Italy.
}

Keywords: Amphibia: Mantellidae, Mantidactylus, subgenus Laurentomantis, Aglyptodactylus, Boophis, Laliostoma, Mantidactylus, Mantella, systematics, phylogeny, radiation, new species, tibial glands, Madagascar.

\begin{abstract}
A revision of species included in the subgenus Laurentomantis (genus Mantidactylus) yielded new information about phylogeny, taxonomy, and biogeography of the endemic mantellid frog radiation in Madagascar. Four Laurentomantis species, distinguished by morphology and advertisement calls, are recognized: Mantidactylus (Laurentomantis) horridus (Northern and NorthWestern biogeographic regions), $M .(L$.$) ventrimaculatus (South-$ East and East); $M_{*}$ (L.) malagasius (East); and the new species $M$. (L.) striatus (North-East). M. striatus and $M$. malagasius are probably sister species based on bioacoustic and morphological affinities. A tibial gland, so far unknown in anurans, is described in $M$. malagasius and $M$. horridus. A phylogenetic analysis of 54 mainly osteological and morphological characters in 33 endemic Malagasy anurans resulted in a position of Laurentomantis close to species of the subgenera Spinomantis and Gephyromantis (genus Mantidactylus), in accordance with its subgeneric status. However, also the well-established genus Mantella resulted to be nested within Mantidactylus, supporting the need of generic partitioning of the latter.
\end{abstract}

\section{Contents}

Introduction

Materials and methods

Systematic accounts

Key to species of Laurentomantis

Phylogenetic analysis

Discussion

Phylogenetic relationships of Laurentomantis

Biogeography
Relationships and origin of mantellids

Acknowledgements

209

References

209

Appendix: Characters used for analysis

\section{Introduction}

Recent phylogenetic studies based on mitochondrial DNA sequences suggested that the endemic Malagasy frogs of the genera Aglyptodactylus, Boophis, Laliostoma (previously Tomopterna), Mantidactylus and Mantella form a monophyletic lineage (Richards and Moore, 1998; Bossuyt and Milinkovitch, 2000; Richards et al., 2000; Vences et al., 2000), although they had been previously assigned to three different subfamilies in the family Ranidae (Blommers-Schlösser, 1993). Based on the genetic evidence, Vences and Glaw (2001) proposed including representatives of the five genera in a separate family Mantellidae, with three subfamilies (Mantellinae, Boophinae, Laliostominae).

Molecular studies on Mantidactylus included single representatives of eight subgenera (Richards et al. 2000), but morphological phylogenies of this genus based on an adequate number of characters and terminal taxa have so far not been published (see Glaw et al., 1998). While Mantella, Aglyptodactylus and Laliostoma are well defined lineages 
with a limited number of species, Boophis and Mantidactylus are speciose, with about 40 and 75 nominal species, respectively. Especially Mantidactylus, currently partitioned into 12 subgenera (Glaw and Vences, 1994), contains very diverse frogs both in size and morphology as well as in habits and reproductive modes. Basic data on ecology and reproductive biology are incomplete or totally lacking for many species of Mantidactylus and Boophis. To understand how the mantellid radiation could give rise to its present extraordinary diversity in Madagascar, it is crucial to gather information on its less known lineages.

Despite of the important recent progress in knowledge on the batrachofauna of Madagascar (Glaw and Vences, 2000), a number of groups remain largely unknown. Such is the case for the frog species classified in Laurentomantis, which at present (Glaw and Vences, 1994) is considered as subgenus of Mantidactylus: Mantidactylus (Laurentomantis) horridus (Boettger, 1880), M. (L.) malagasius (Methuen and Hewitt, 1913) and $M$. (L.) ventrimaculatus (Angel, 1935). The monograph of Blommers-Schlösser and Blanc (1991) contained no information on habitat, biology or life coloration of any Laurentomantis species. BlommersSchlösser and Blanc (1993) showed, for the first time, a photograph of a living M. malagasius. Glaw and Vences (1994) provided photographs, call descriptions and natural history notes for two different morphs referred to this species from the Central East and Marojejy in the North-East, and reported the discovery of an adult $M$. horridus at Montagne d'Ambre in northern Madagascar.

The nomenclatural and taxonomic history of Laurentomantis is extensive and still confusing. While Boettger (1880) described the taxon horridus as Hemimantis horrida, Boulenger (1882) treated this species as Arthroleptis horridus. Methuen and Hewitt (1913) erected the genus Microphryne to accomodate their taxon malagasius (as $M$. malagasia), and assumed that horrida belonged to this genus as well. As the name Microphryne was preoccupied, Methuen (1920) created the replacement name Trachymantis. However, as demonstrated by Dubois (1980), Trachymantis was also preoccupied (by Trachymantis Giglio-Tos, 1917). Dubois (1980) thus created the replacement name Laurento- mantis, which was considered to merit genus rank by Blommers-Schlösser and Blanc (1991) and Dubois (1992). Glaw and Vences (1994), however, concluded that no phylogenetic data exist to consider Laurentomantis as a separate genus in addition to the speciose Mantidactylus, and consequently considered Laurentomantis as a subgenus of Mantidactylus.

During the last years, numerous additional specimens of Laurentomantis were collected during surveys in several regions of Madagascar. In the present paper we review the Laurentomantis material available to us (more than 45 specimens), provide detailed morphological and bioacoustic data, and describe one new species. We furthermore undertake a phylogenetic analysis of 33 species, representing all mantellid genera, to assess the position of Laurentomantis relative to them, and to draw hypotheses on the origin and evolution of this radiation.

\section{Materials and methods}

Vocalizations were recorded using portable tape recorders with external microphones and were analyzed either with the MEDAV sound analyzing system Spektro 3.2 (M. malagasius, $M$. striatus, $M$. ventrimaculatus) or on a $\mathrm{PC}$ using the software CoolEdit (Syntrillium Software Corp.) (M. horridus).

The following morphological measurements were taken with a calliper to the nearest 0.1 millimeter: SVL (snout-vent length), HW (head width), HL (head length), ED (horizontal eye diameter), END (eye-nostril distance), NSD (nostril-snout tip distance), NND (nostril-nostril distance), TD (horizontal tympanum diameter), HAL (hand length), FORL (forelimb length), HIL (hindlimb length), FOL (foot length), FOTL (foot length including tarsus), IMTL, IMTH (length and height of inner metatarsal tubercle), TL1 (length of first toe).

Institutional abbreviations are as follows: BMNH (The Natural History Museum, London); FAZC (Franco Andreone Zoological collection; preliminary numeration of specimens which will be deposited in MRSN); FMNH (Field Museum, Chicago); MNHN (Muséum National d'Histoire Naturelle, Paris); MRSN (Museo Regionale di Scienze Naturali, Torino); MSNG (Museo di Storia Naturale di Genova); NMBE (Naturhistorisches Museum Bern); PBZT (Parc Botanique et Zoologique de Tsimbazaza, Antananarivo); TM (Transvaal Museum, Pretoria); UADBA (Universitě d'Antananarivo, Département de Biologie Animale); ZFMK (Zoologisches Forschungsinstitut und Museum Alexander Koenig, Bonn); ZMA (Zoölogisch Museum, Amsterdam); ZSM (Zoologische Staatssammlung München).

Statistical analyses were carried out using SPSS for Windows, version 9. We performed Mann-Whitney U-tests to assess sig- 
nificance of intersexual and interspecific differences in size and morphometric ratios (relative tympanum length and head width, ratios TD/SVL and HW/SVL; relative size of inner metatarsal tubercle, IMTL/SVL and IMTH/SVL). Temporal and metric measurements are given as range, with mean \pm standard deviation in parentheses. Terminology for the description of femoral and tibial glands follows Glaw et al. (2000). Number of crossbands on hand and foot are given to the tip of the longest finger or toe, respectively. The term "tibial gland" is here coined for the prominent gland structures on the dorsal surface of the tibiae of Mantidactylus horridus and $M$. malagasius (see descriptions in the corresponding sections). The terms femur, tibia, humerus and radius, in the descriptive species accounts, are used to refer to the corresponding external limb segments, and not to the bones.

Coordinates and altitude of collecting localities are listed in Vences and Glaw (submitted). Full names and geographic references of the campsites visited by F. Andreone and quoted in the text are as follows: (1) Masoala Campsite 2 = Forêt de Beanjada, $15^{\circ} 16.8^{\prime} \mathrm{S}, 49^{\circ} 59.8^{\prime} \mathrm{E}, 620 \mathrm{~m}$, Masoala Peninsula, Antalaha Fivondronana, Antsiranana (Diégo Suarez) Faritany (Province); (2) Masoala Campsite 3= Forêt d"Andasin'1 Governera, $15^{\circ} 18.3^{\circ} \mathrm{S}, 50^{\circ} 01.2^{\circ} \mathrm{E}, 700 \mathrm{~m}$, Masoala Peninsula, Antalaha Fivondronana, Antsiranana (Diégo Suarez) Faritany (Province); (3) Ilampy = Masoala Peninsula, Campsite 4 (Antsarahan'Ambararato), $15^{\circ} 23.52 ' \mathrm{~S}, 50^{\circ} 02.82^{\prime} \mathrm{E}, 510 \mathrm{~m}$, Antalaha Fivondronana, Antsiranana Faritany (Diégo Suarez Province); (4) Tsararano Campsite 1 = Tsararano Forest, Campsite 1 (Antsarahan'ny Tsararano), Andapa Fivondronana, Antsiranana Faritany (Diégo Suarez Province), $14^{\circ} 54.4^{\prime} \mathrm{S}, 49^{\circ} 41.2^{\prime} \mathrm{E}, 700 \mathrm{~m}$.

Osteological data refer to the cleared and stained specimens listed in Table III. Terminology and character definitions largely follow the accounts of Clarke (1981), Drewes (1984), BlommersSchlösser (1993), Glaw and Vences (1994), and Glaw et al. (1998). Characters were analyzed with PAUP*, version 4 beta (Swofford 1998). We performed Maximum parsimony (MP) analyses (heuristic searches with TBR branch swapping), coding all characters as unordered. Multistate characters were coded as polymorphisms. Species of Heterixalus (Hyperoliidae) were used as outgroup (see Blommers-Schlösser, 1993; Glaw et al., 1998).

\section{Systematic accounts}

\section{Laurentomantis Dubois, 1980}

Status. - A subgenus of Mantidactylus Boulenger, 1895 following Glaw and Vences (1994).

Diagnosis: - Small to medium sized (SVL 20-35 $\mathrm{mm}$ ) scansorial anurans with a moderately to coarsely granular dorsum and completely connected lateral metatarsalia. Webbing absent from hand and feet. Third toe distinctly longer than fifth toe. A single inner and two outer metacarpal tubercles; a distinct inner and a small outer metatarsal tubercle; single subarticular tubercles. Intercalary element present between ultimate and penultimate phalanges of all fingers and toes. Ultimate phalanges $\mathrm{Y}$-shaped. Omosternum ossified and unforked. Vertebral column diplasiocoelous. Maxillary teeth present, vomerine teeth present (vomerine odontophore present), but generally concealed under mucous skin of buccal roof. A complete circummarginal groove ventrally on finger and toe pads. Males with a slightly distensible single subgular vocal sac and distinct femoral glands, of type 2 according to Glaw et al. (2000) as assessed by detailed macroscopic examinations, composed of up to nine single large granules; some species with tibial glands; no nuptial pads.

Included species. - Mantidactylus horridus, $M$. malagasius, $M$. striatus sp. n., M. ventrimaculatus.

\section{Mantidactylus (Laurentomantis) horridus (Boettger, 1880)}

Fig. 1a-b

Material. - SMF 7177 (holotype, Nosy Be, collected by C. Ebenau); MSNG 49125A-C and UADBA 10001-10002 (Manarikoba Forest, Tsaratanana Massif, 1402'24''S, 48 $47^{\circ} 02^{\prime \prime} \mathrm{E}$; R. Jesu, G. Schimmenti and J. C. Piso, 15-22 February 1997); ZFMK 57433 (Montagne d'Ambre; F. Glaw, N. Rabibisoa and O. Ramilison, 14-17 March 1994).

\section{Original name. - Hemimantis horrida Boettger, 1880}

Identity. - The holotype is a subadult specimen of $16.4 \mathrm{~mm} \mathrm{SVL}$; it agrees with the other specimens assigned here to the taxon in general morphology and coloration (coarsely granular without distinct ridge elements on the dorsum, with two indistinct broad dark transversal bands), by having short hindlimbs (tibiotarsal articulation reaching anterior eye corner), lacking an unpigmented area on the posterodorsal part of the femur (on which the original pigmentation is still rather well preserved). The area immediately above the cloaca has a very short light marking which may be homologous to the vertebral stripe on the posterior dorsum typical for the new species $M$. striatus (see below). 

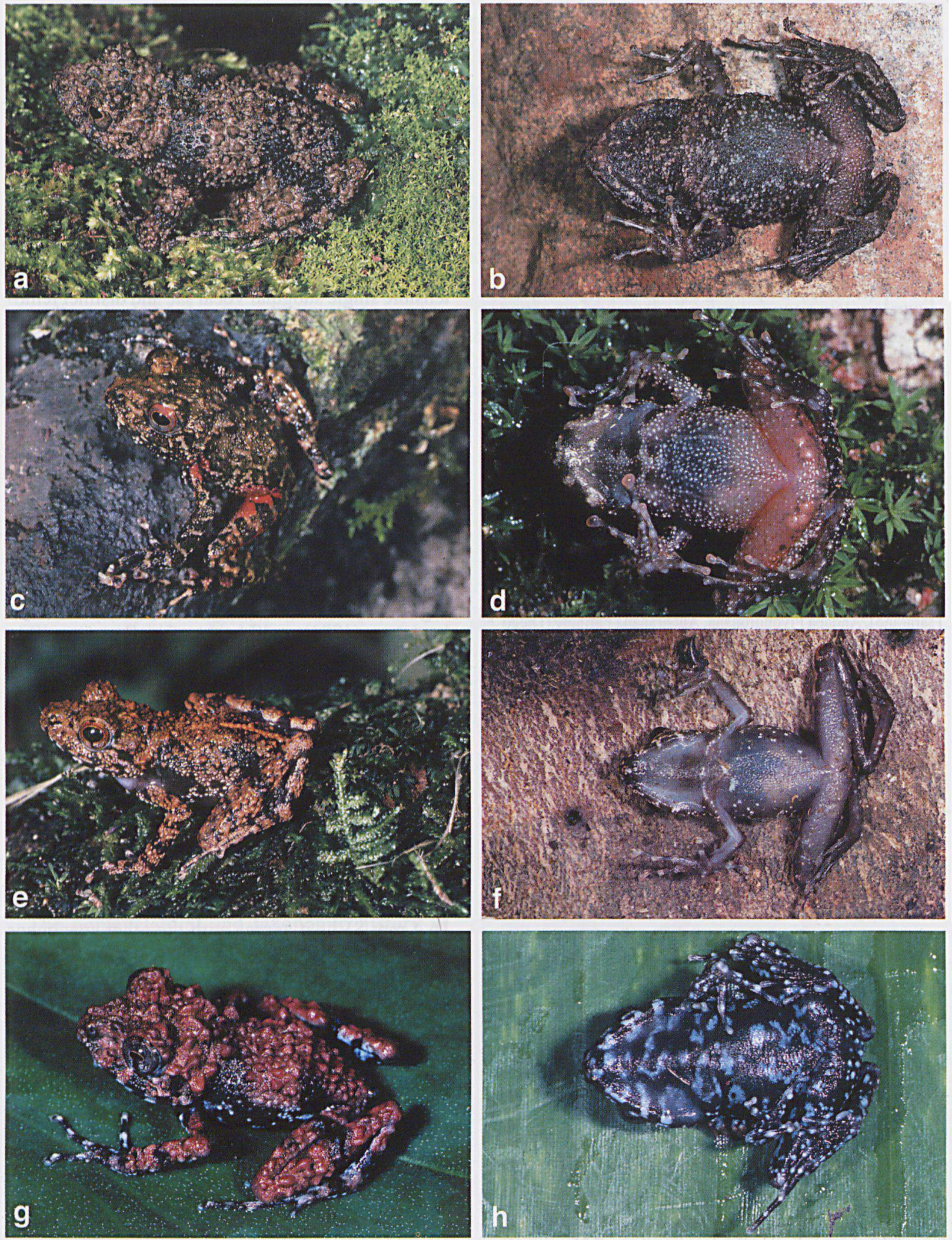
Diagnosis. - Distinguished from other known Laurentomantis by larger body size (male SVL 26-28 mm vs. $20-25 \mathrm{~mm}$; female SVL $35 \mathrm{~mm}$ vs. $23-29$ $\mathrm{mm})$, long note duration (1271-2521 ms vs. 407 $1468 \mathrm{~ms}$ ) and low pulse repetition rate in advertisement calls (13/s vs. $18-40 / \mathrm{s})$. Further distinguished from $M$. ventrimaculatus by absence of prominent dorsal ridges, from $M$. ventrimaculatus and $M$. striatus by a granular belly, and from $M$. malagasius by absence of red color on limbs.

Morphology. - For measurements see Tables I and II. The skin of the dorsum is coarsely granular; granules are only sometimes indistinctly arranged as continuous ridges on the anterior back (e.g. UADBA 10001). The vocal sac, as far as recognizable in preserved specimens, is single subgular. Throat and limbs are ventrally smooth, the belly is granular. A tibial gland is present in all male specimens from Tsaratanana (although less prominent than in $M$. malagasius), but absent in the single female from Montagne d'Ambre. Femoral glands in MSNG $49125 \mathrm{C}$ (size $3.6 \times 1.9 \mathrm{~mm}$; Fig. 2) in internal view consist of five granules on one limb and six granules on the other limb (granule diameter $0.8-1.3 \mathrm{~mm}$ ). The tibial gland in this specimen, in internal view, has a structure similar to that found in femoral glands of type 2 sensu Glaw et al. (2000). It consists of a densely packed field of ca. 60 granules (granule diameter 0.2-0.4 mm). Externally, about 60 distinct pores are visible on the gland surface (absent from the surrounding skin), indicating that each granule may have one separate secretion pore (Fig. 3). Size of the tibial gland is $8.0 \times 2.2 \mathrm{~mm}$.

No significant sexual dimorphism in relative tympanum size and relative size of inner metatarsal tubercle was detected in the single female available. Mean male size was $76 \%$ of female size.

Coloration. - In preservative, dorsally greyish brown with a very faint and poorly delimited dark pattern which forms 2-3 indistinct broad transversal bands. Limbs with dark crossbands of variable width: 2-4 on femur, 2-3 on tibia, 7-8 on tarsus and foot, 1-2 on humerus, 4-5 on radius and hand. Ventral side uniformly diffuse greyish-brown with small light grey (throat and belly) or cream (limbs) markings. In life similar. The light ventral markings were rather indistinct. The iris was yellowish brown, with a narrow, more intense orange circle around the pupil.

Distribution. - Known from (1) the type locality Nosy Be, (2) Montagne d'Ambre, and (3) Tsaratanana (altitude $1300 \mathrm{~m}$ ) (Fig. 5). At Montagne d'Ambre, the species has also been recorded at an altitude of $1200 \mathrm{~m}$ by Raxworthy and Nussbaum (1994). The highest elevation of the island of Nosy $\mathrm{Be}$ is $430 \mathrm{~m}$ in the Lokobe reserve. Altitudinal range is therefore $430 \mathrm{~m}$ (probably also lower altitudes at Nosy Be) to $1300 \mathrm{~m}$. Blommers-Schlösser and Blanc (1991) listed three further localities: Marojejy, Fenerive and Tampolo. While the latter two localities both refer to the specimen MNHN 1953.130 which is here assigned to $M$. malagasius (see section on distribution of that species), we did not find any voucher for the locality Marojejy in the MNHN and ZMA collections on which the distributional data of Blommers-Schlösser and Blanc (1991) were largely based; the Marojejy locality which possibly refers to $M$. striatus - is therefore considered in need of confirmation. The specimen shown as $M$. horridus in Hofrichter (1998) is actually a $M$ : ventrimaculatus (NMBE 268/96, see below).

Natural history. - On the Tsaratanana Massif, $M$. horridus was collected within the primary rainforest of Manarikoba, which was described by Perrier de la Bathie (1927) and characterised by trees heavily covered with mosses and herbaceous under-

\footnotetext{
$\leftarrow$
}

Fig. 1. Dorsolateral and ventral views of species in the subgenus Laurentomantis in life. a-b, Mantidactylus (Laurentomantis) horridus, female ZFMK 57433 from Montagne d'Ambre; c-d, Mantidactylus (Laurentomantis) malagasius, male from Andasibe; ef, Mantidactylus (Laurentomantis) striatus, male from Marojejy; $\mathrm{g}-\mathrm{h}$, Mantidactylus (Laurentomantis) ventrimaculatus, male from Vohiparara. 


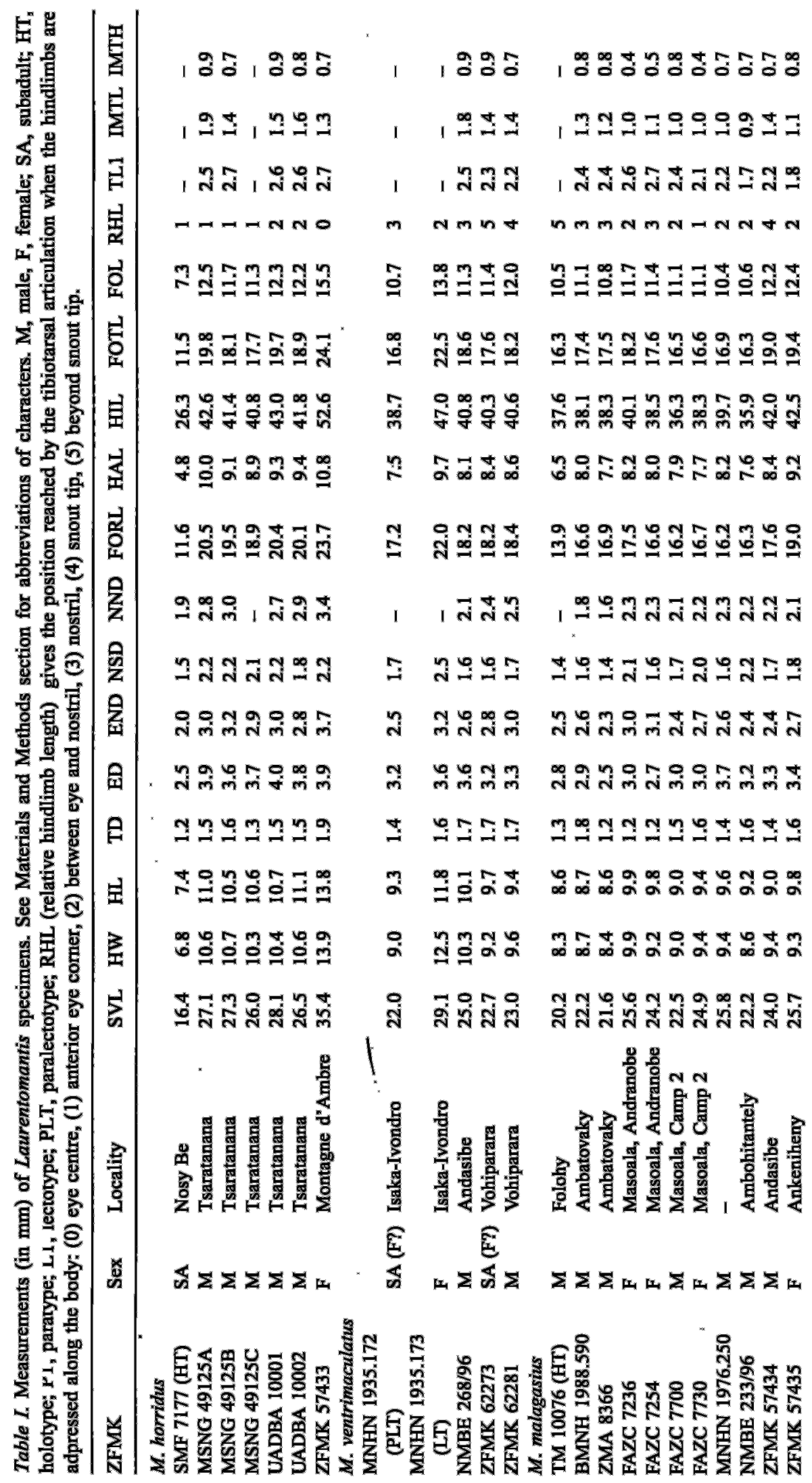




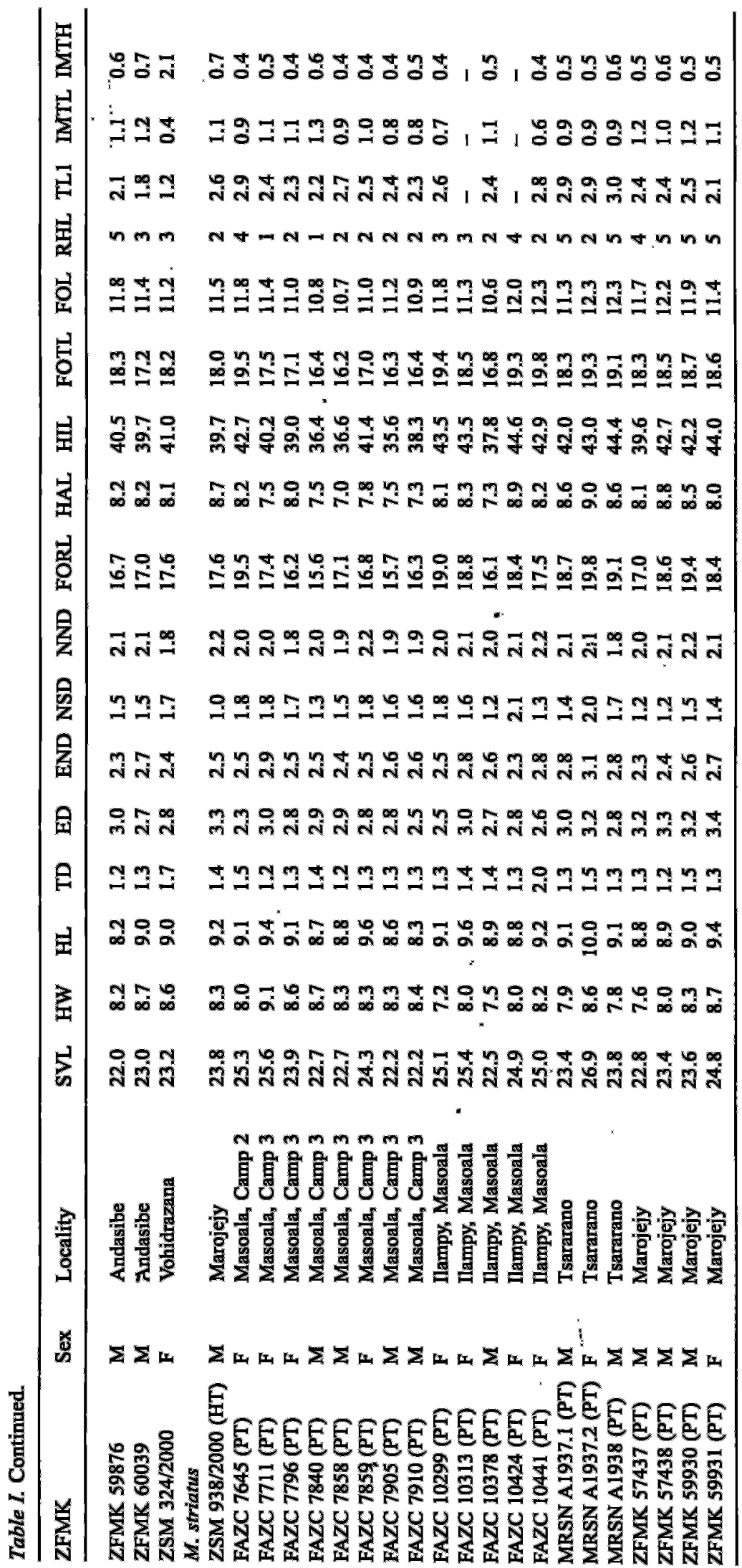


Table II. Differential characters of Laurentomantis species. Morphometric ratios were calculated from data in Table I. TT is used as abbreviation for tibiotarsal articulation.

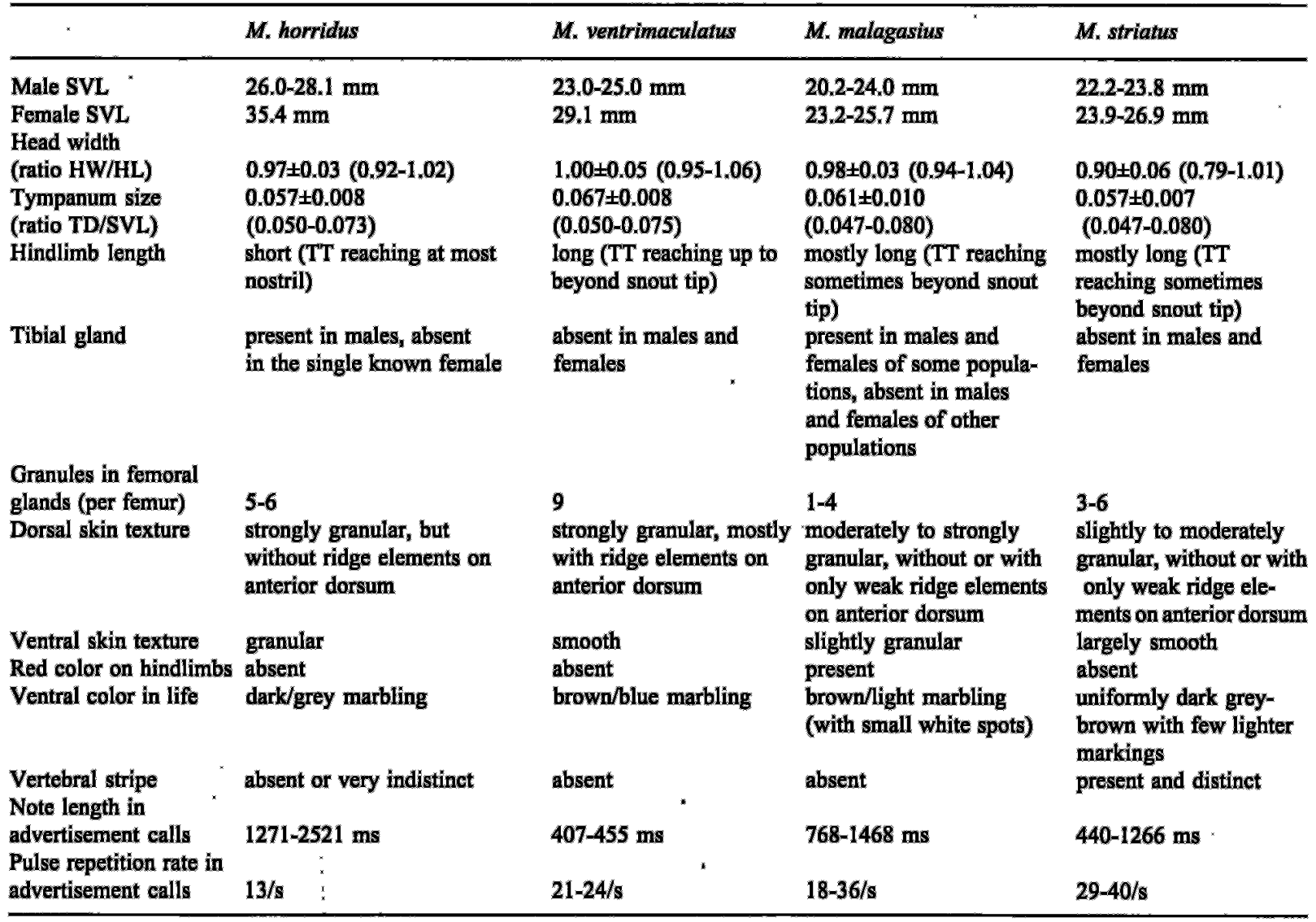

growth. The physionomy of this unspoilt forest is also marked by the presence of high numbers of tree ferns (Cyathea) and Pandanus. During the study period (15-22 February 1997), which occurred in the peak of the rainy season, only calling males were observed: they were spotted at night on bushes at $50-150 \mathrm{~cm}$ from the ground in the vicinity of a mountain stream. The female from Montagne d'Ambre was found hidden under deadwood in primary forest (Glaw and Vences, 1994).

Calls. - Recorded on the Tsaratanana Massif on 17 February 1997 , at $17.5^{\circ} \mathrm{C}$ air temperature. Calls were series of long notes with widely spaced pulses (Fig. 4a). Note duration was 1271-2521 ms (2116 \pm $440 \mathrm{~ms}, \mathrm{n}=7$ ), duration of intervals between notes was $1271-3113 \mathrm{~ms}(1846 \pm 589 \mathrm{~ms}, \mathrm{n}=7)$. Each note consisted of $16-33(27.3 \pm 5.9 ; n=7)$ pulses. Pulse duration was $11-17 \mathrm{~ms}(14 \pm 2 \mathrm{~ms}, \mathrm{n}=15)$, duration of intervals between pulses was 52-64 ms (58 $4 \mathrm{~ms}, \mathrm{n}=15$ ). Pulse repetition rate was 12.6-13.3 $(12.9 \pm 0.3 ; n=7)$ per second. Pulse intensity increased at the beginning of one note, and decreased again towards its end. Frequency was $2300-4300 \mathrm{~Hz}$, dominant frequency $2300-3300 \mathrm{~Hz}$.

\section{Mantidactylus (Laurentomantis) ventrimaculatus (Angel, 1935)}

Fig. 1g-h

Material. -MNHN 1935.173 (lectotype) and MNHN 1935.172 (paralectotype), both from Isaka-Ivondro, collected by R. Catala; ZFMK 62273 and 62281 (Vohiparara; F. Glaw, D. Rakotomalala and F. Ranaivojaona, 27 February 1996); NMBE 268/96 (Andasibe-Analamazaotra; D. Vallan, 25 January 1996). 
Original name. - Trachymantis malagasia var. ventrimaculatus Angel, 1935

Identity. - The morphological and chromatic characters of the types (light marbling on venter; relatively long hindlimbs; dorsal ridges) leave little doubts on the correct attribution of the Vohiparara and Andasibe specimens to $M$. ventrimaculatus.

Diagnosis. - Distinguished from other known Laurentomantis by short note duration in advertisement calls (407-455 ms vs. 440-2521 ms). Further distinguished from $M$. horridus by smaller body size (male SVL 23-25 mm vs. 26-28 mm), smooth belly, and higher pulse repetition rate in advertisement calls (21-24/s vs. $13 / \mathrm{s})$; and from $M$. striatus and $M$. malagasius by dark belly with distinct light marblings (which are bluish in life).

Morphology. - For measurements see Tables I and II. The skin of the dorsum is strongly granular. Tubercles on the posterior head and anterior dorsum fuse to form a symmetrical pattern of ridges. These ridges are prominent in most specimens, rigid and of a sharp appearance. A tibial gland is absent in NMBE and ZFMK material, both in the males and in the subadult (female) specimens. Venter and throat are smooth, very slightly granular areas are present on the belly close to the inguinal region. Femoral glands are very distinct and prominent; in ZFMK 62281, the ovoid gland consists of 9 large granules which in internal view are regularly packed but in external view appear to enclose two median depressions. This external configuration is even better visible in NMBE 268/96 (Fig. 5), in which the gland measures $5.6 \times 3.0 \mathrm{~mm}$. Diameter of single granules is $0.9 \mathrm{~mm}$.

No significant sexual dimorphism in relative tympanum size and relative size of inner metatarsal tubercle was detected. Mean male size was $82 \%$ of mean female size (only adult specimens considered).

Coloration. - In preservative, dorsally greyish brown with two indistinct, faintly recognizable dark crossbands which are largely discontinuous dorsally but rather distinct on the flanks. Limbs with distinct " and regular crossbands: $2-3$ on femur, 3 on tibia,

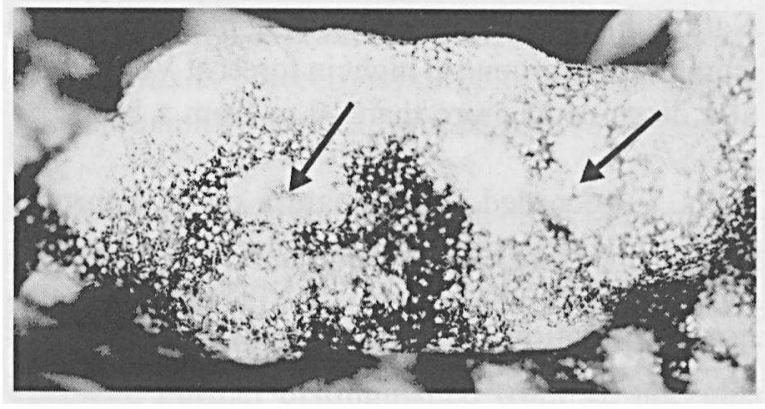

Fig. 2. Femoral gland of Mantidactylus (Laurentomantis) ventrimaculatus (NMBE 268/96) in ventral (external) view. Arrows indicate the apparent external central depressions which may be used by the surrounding gland granules for secretion.

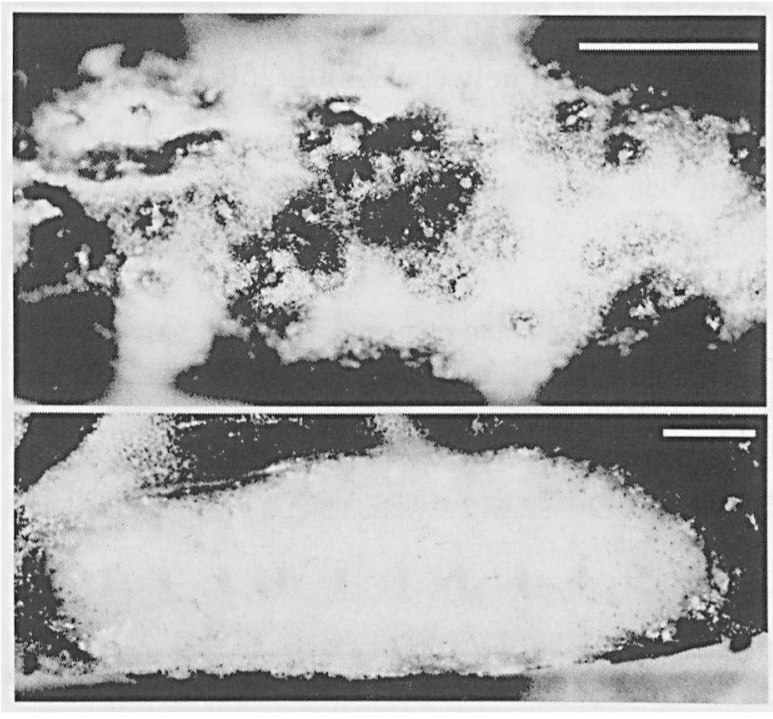

Fig. 3. Tibial gland of Mantidactylus (Laurentomantis) horridus (MSNG 49125C) in external view (above) and internal view (below). Note the large number of small secretion pores in external view. Scale bars $=1 \mathrm{~mm}$.

7 on tarsus and foot, 1-2 on humerus, 6 on radius and hand. Ventral side dark brown, distinctly marbled with grey. In life, the dorsum was reddish brown and the ventral light marbling was light blue on a deep black venter and throat. The iris was greyish brown, with a narrow vertical black streak in its lower part. The crossbands on the flanks were deep black.

Distribution. - Known from (1) the type locality Isaka-Ivondro (at an altitude of $700 \mathrm{~m}$ according to original description), (2) Vohiparara, and (3) Andasibe (Fig. 3). Altitudinal range 700-1000 m. 
Natural history. - A single calling male was heard from near the ground at night in forest at Vohiparara, at a distance of more than $10 \mathrm{~m}$ from a brook.

Calls. - Recorded at Vohiparara on 27 February 1996. Calls were series of unharmonious notes (Fig. $4 d)$. Note duration was $407-455 \mathrm{~ms}(442 \pm 19 \mathrm{~ms}$, $\mathrm{n}=7$ ), duration of intervals between notes was 2673-6274 ms ( $3452 \pm 1281 \mathrm{~ms}, \mathrm{n}=7)$. Each note consisted of $9-11(9.9 \pm 0.7, \mathrm{n}=7)$ pulses. Pulse duration was $5-19 \mathrm{~ms}(13 \pm 4 \mathrm{~ms}, \mathrm{n}=75)$, duration of intervals between pulses was $28-48 \mathrm{~ms}$ (36 $\pm 4 \mathrm{~ms}, \mathrm{n}=66)$. Pulse repetition rate was 21-24 $(22 \pm 1, n=7)$ pulses per second. Frequency ranged between $2000-5750 \mathrm{~Hz}$, the poorly defined dominant frequency between $2300-4250 \mathrm{~Hz}$.
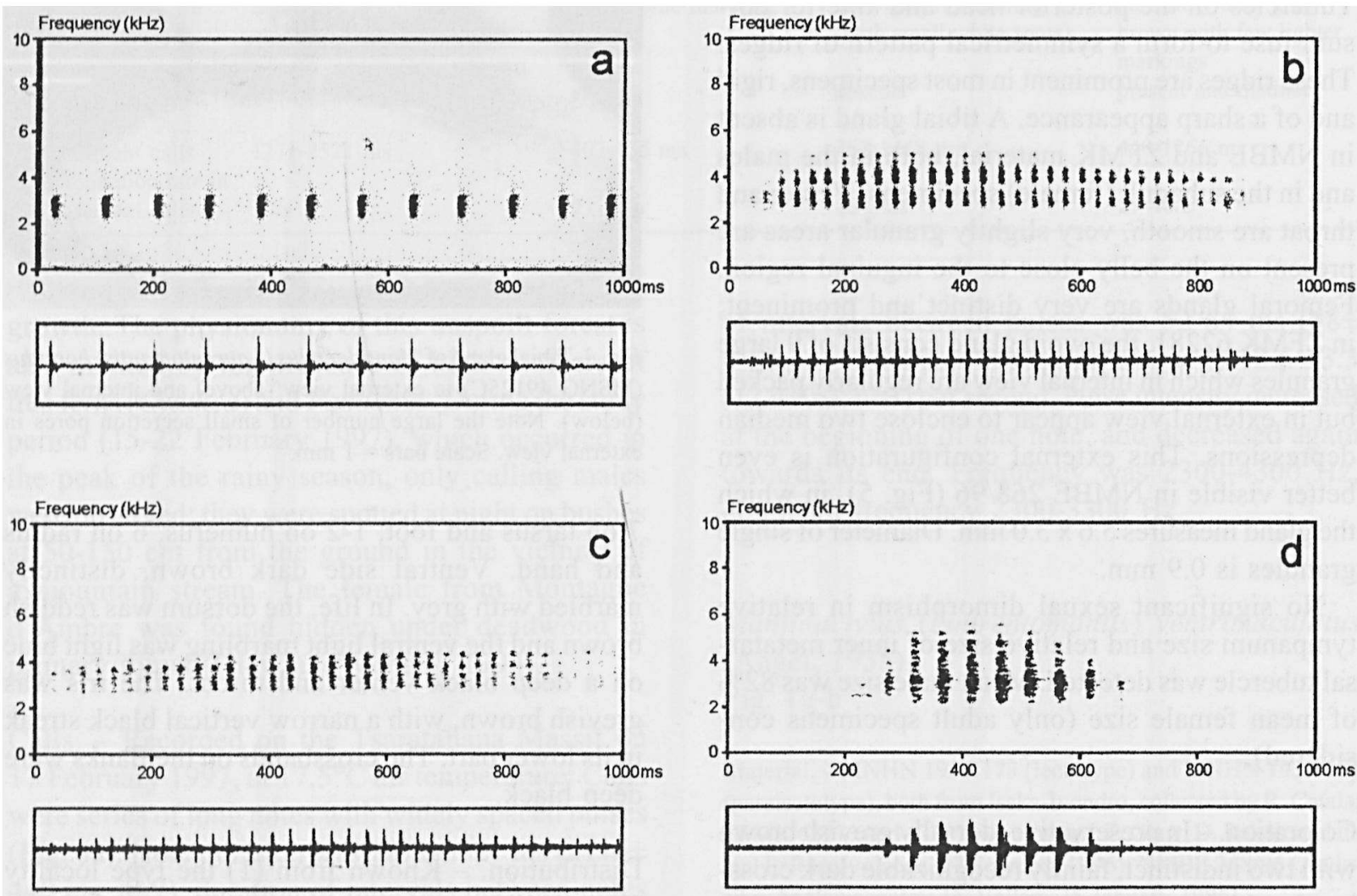

Mantidactylus (Laurentomantis) malagasius (Methuen and Hewitt, 1913)

Fig. 1c-d

Material. - BMNH 1988.590 (Ambatovaky, 400 m, C. J. Raxworthy 13 March 1990); FAZC 7236 and 7254 (Andranobe, Masoala; J. E. Randrianirina, 28 October - 6 November 1998); FAZC 7700 and 7730 (Masoala, Campsite 2; F. Andreone and J. E. Randrianirina, 30 November 1998); MNHN 1976.250 (locality unknown); MNHN 1953.130 (Tampolo Est); NMBE 233/96 (Ambohitantely; D. Vallan); TM 10076 (holotype; Folohy; collected by M. Herschell-Chauvin, apparently in 1911); ZFMK 57434 and 59876 (Andasibe; F. Glaw and M. Vences, 1-4 January 1994); ZFMK 57435 (Ankeniheny; F. Glaw, N. Rabibisoa and O. Ramilison, 19 February 1994); ZFMK 60039 (Andasibe; F. Glaw, 1 February 1995); ZMA 8366 (Ambatovaky; C. J. Raxworthy, March 1990); ZSM 324/2000 (Vohidrazana, F. Glaw, 10 April 2000).

Original name. - Microphryne malagasia Methuen and Hewitt, 1913
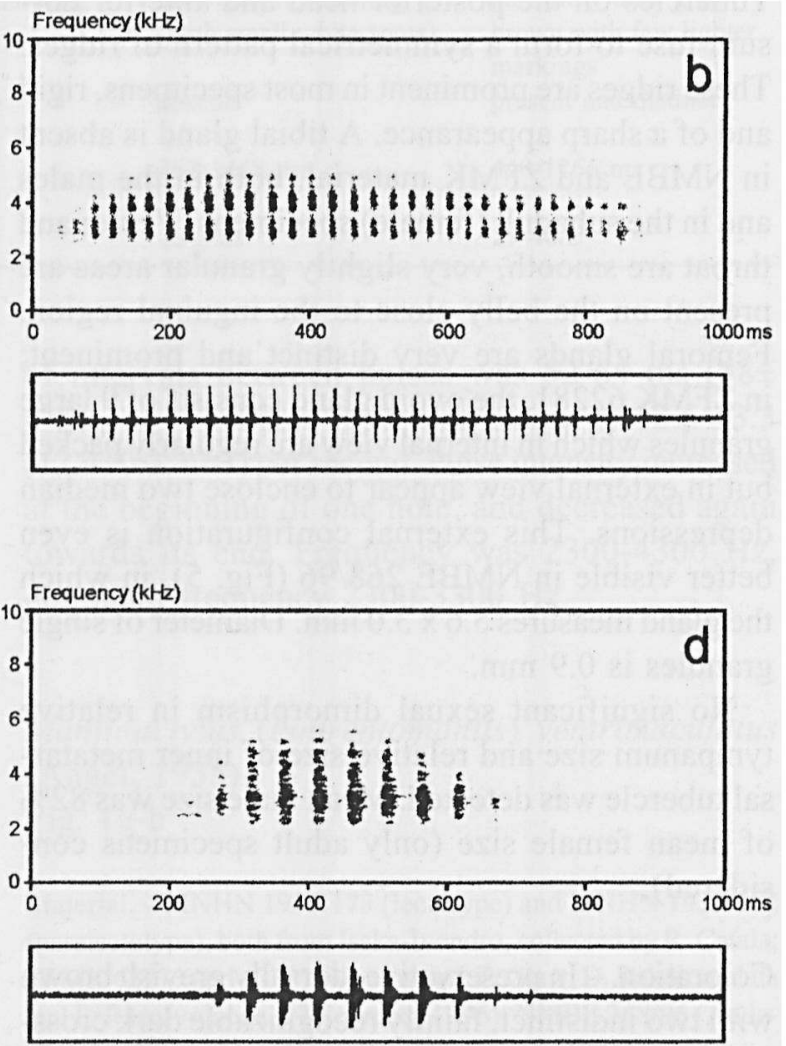

Fig. 4. Sonagrams and oscillograms of calls of species in the subgenus Laurentomantis, a, Mantidactylus horridus, recorded at Tsaratanana; b, Mantidactylus malagasius, recorded at Andasibe; c, Mantidactylus striatus, recorded at Marojejy; d, Mantidactylus ventrimaculatus, recorded at Vohiparara. 


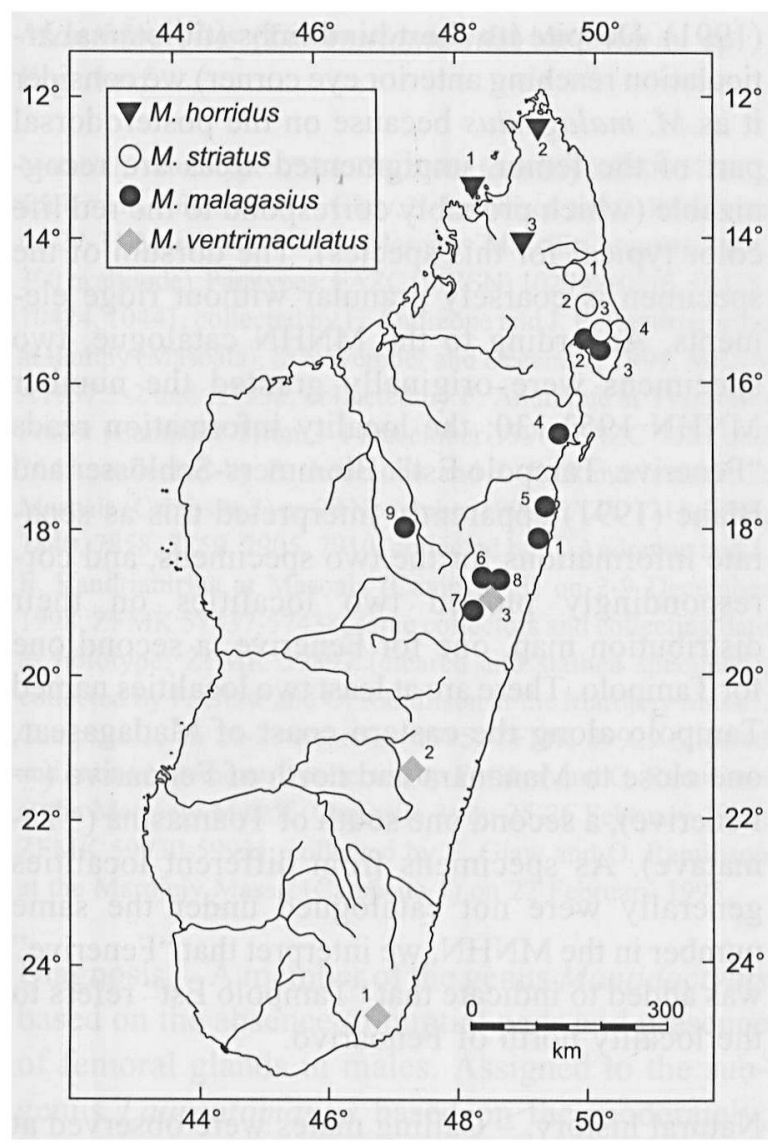

Fig. 5. Distribution map of species in the subgenus Laurentomantis. Positioning of localities in the maps is in part only approximate. Numbers of localities correspond to those given in the "Distribution" sections of each species.

Identity. - The male holotype is characterized by a coarsely granular dorsal skin, with two ridgelike granules in the shoulder region and two larger rounded granules on the anterior dorsum; throat and chest are smooth, venter and ventral surface of femur are slightly granular. Femoral glands are prominent. The gland on the left femur consists of one single enlarged granule, diameter ca. $1.8 \mathrm{~mm}$; the gland on the right femur consists of two granules (see also Methuen and Hewitt, 1920). There are no tibial glands. Color (after about 90 years in preservative) has largely faded into an almost uniform light brown. According to the original description, "hidden surface of the thighs and tibiae with large white blotches" which almost certainly correspond to the unpigmented areas (red in life) typical for this species. Furthermore, the general morphology, size, and structure of the femoral gland (composed of 1-2 granules) indicate that the name malagasius is correctly applied to the red-legged Laurentomantis species from eastern Madagascar.

Diagnosis. - Distinguished from other known Laurentomantis by red color on posterior and ventral surface of limbs (appearing pigmentless in preservative vs. pigmented brown-greyish in the other species). Further distinguished from $M$. horridus by shorter note duration (768-1468 ms vs. 1271$2521 \mathrm{~ms}$ ) and higher pulse repetition rate in advertisement calls (18-36/s vs. $13 / \mathrm{s})$, and smaller body size (male SVL $20-24$ vs. $26-28 \mathrm{~mm}$; female SVL $23-26 \mathrm{~mm}$ vs. $35 \mathrm{~mm}$ ); from $M$. ventrimaculatus by absence of regular light marbling (bluish in life) on a dark venter, and longer note duration in advertisement calls (768-1468 ms vs. $407-455$ $\mathrm{ms}$ ). For a distinction from $M$. striatus, see diagnosis of that species below.

Remark. - The specimen MNHN 1976.250 differs in general appearance and femoral gland morphology from the remaining specimens; it is only tentatively assigned to M. malagasius, and not considered in the morphometric calculations.

Morphology. - For measurements see Tables I and II. The dorsum is moderately granular, the granules only occasionally form ridge-like structures which, however, are never very prominent. The throat is smooth, the belly slightly to moderately granular. Very distinct and prominent tibial glands are present in the males from Andasibe and Ambohitantely as well as in the female from Ankeniheny (ZFMK 57435). They are also present in the dubious specimen MNHN 1976.250, but absent in the male holotype and in specimens from Ambatovaky and Andranobe (Masoala). This may indicate a constant difference between mid-altitude and low altitude localities, but more material is necessary to assess whether it may bear taxonomic relevance. In ZFMK 57434, the tibial gland measures $7.1 \mathrm{x}$ $1.4 \mathrm{~mm}$ and consists (in internal view) of about 75 granules (0.2-0.4 $\mathrm{mm}$ in diameter). The external pores of the gland are clearly visible.

Femoral glands are only present in males; on each femur, the gland generally consists of two large granules (a single granule in the holotype); 
in BMNH 1988.590 from Ambatovaky, the gland on each femur consists of two groups of two granules each (total number of granules on both femurs: eight). Femoral gland size in NMBE 233/96 is $3.1 \times 1.4 \mathrm{~mm}$ in external view (diameter of each granule in internal view ca. $1.2 \mathrm{~mm}$ ).

No significant sexual dimorphism in relative tympanum size and relative size of inner metatarsal tubercle was detected. Mean male size was $92 \%$ of mean female size.

Coloration. - In preservative, dorsally greyish brown, with indistinct dark pattern. Except short brown crossbands, the femur is pigmentless. There are 3-5 crossbands on femur, 4-5 on tibia, 8-10 on tarsus and foot, 6-7 on radius and hand; no distinct bands are seen on humerus. Ventrally grey-brown on throat, chest and anterior belly, pigmentlesscream on posterior belly. A pattern of small white spots, partly forming aggregations, is present on the dark ventral areas. On the belly, each of these spots coincides with a single granule. Along the lower lip, the light spots sometimes form crossbands (e.g. ZFMK 59876). Ventral side of forelimbs brown with light spots. Femur ventrally pigmentless cream, tibia cream with brown markings. In life, the posterior and ventral surfaces of the femur are deep red, as is part of the inguinal region and of a small area around the forelimb insertion. The femurs and posterior belly are more or less intensively shaded red. The iris is orange brown in its upper part, greyish in its lower part. The dorsal surface can have an olive-greenish shade.

Distribution. - The species is known from (1) the type locality Folohy, (2) Andranobe (Masoala), ( $\beta$ ) Masoala (other localities), (4) Ambatovaky, (5) Fenoarivo, (6) Andasibe, (7) Ankeniheny, (8) Vohidrazana, (9) Ambohitantely (Fig. 3). The known altitudinal range is $300-900 \mathrm{~m}$.

The specimens BMNH 1928.5.9.13 (Brickaville; purch. Rosenberg) and BMNH 1925.7.2.92 (Antsihanaka; purch Rosenberg) were not available at the time of our study and cannot be confirmed as $M$. malagasius until examined. The specimen from Fenerive (MNHN 1953.130) is subadult (SVL 15.2 $\mathrm{mm}$; traces of femoral glands recognizable) and in mediocre state of preservation. It was considered as $M$. horridus by Blommers-Schlösser and Blanc
(1991). Despite its short hindlimbs (tibiotarsal articulation reaching anterior eye corner) we consider it as $M$. malagasius because on the posterodorsal part of the femur, unpigmented areas are recognizable (which probably correspond to the red life color typical for this species). The dorsum of the specimen is coarsely granular without ridge elements. According to the MNHN catalogue, two specimens were originally granted the number MNHN 1953.130; the locality information reads "Fenerive, Tampolo Est". Blommers-Schlösser and Blanc (1991) apparently interpreted this as separate informations for the two specimens, and correspondingly plotted two localities on their distribution map, one for Fenerive, a second one for Tampolo. There are at least two localities named Tampolo along the eastern coast of Madagascar, one close to Mananara and north of Fenoarivo (= Fenerive), a second one south of Toamasina ( $=$ Tamatave). As specimens from different localities generally were not catalogued under the same number in the MNHN, we interpret that "Fenerive" was added to indicate that "Tampolo Est" refers to the locality north of Fenoarivo.

Natural history. - Calling males were observed at night in forest in the vegetation, $5-50 \mathrm{~cm}$ above the ground, not concentrated around water bodies. The vocal sac was single subgular and only slightly distensible.

Calls. - Recorded at Ankeniheny at $23.5^{\circ} \mathrm{C}$ air temperature and at Andasibe. Series of unharmonious notes (Fig. 4b). Note duration was 936-1468 ms $(1169 \pm 205 \mathrm{~ms}, \mathrm{n}=6)$ at Andasibe and 768$995 \mathrm{~ms}(864 \pm 72 \mathrm{~ms}, \mathrm{n}=12)$ at Ankeniheny. Duration of intervals between notes was 769-1049 ms $(876 \pm 108 \mathrm{~ms}, \mathrm{n}=5)$ at Andasibe, and 1126$1698 \mathrm{~ms}(1433 \pm 200 \mathrm{~ms}, \mathrm{n}=11)$ at Ankeniheny. Each note consisted of 22-43 $(35 \pm 9, \mathrm{n}=6)$ respectively $15-20(17 \pm 2, n=12)$ pulses. Duration of intervals between pulses at the two localities was 30-80 ms. Pulse repetition rate was 23-36 (30 $\pm 5, \mathrm{n}=6)$ respectively $18-22(20 \pm 11, \mathrm{n}=13)$ pulses per second. Frequency was $2500-4500$ respectively $2650-4400 \mathrm{~Hz}$. 
Mantidactylus (Laurentomantis) striatus n. $\mathrm{sp}$.

Fig. 1e-f

Material. -Holotype: ZSM, 938/2000 (formerly ZFMK 57436), adult male, collected by F. Glaw, N. Rabibisoa and O. Ramilison on 27-31 March 1994 at the Marojejy Massif, Campsite 1 (ca. 300 m altitude). Paratypes: FAZC (MRSN) 10299, 10313, 10378, 10424, 10441, collected by F. Andreone and J. E. Randrianirina at Ilampy (Masoala), in November and December 1999. MRSN A1937.1-2 and A1938, collected by F. Andreone at Tsararano Forest (Campsite 1) on 3-4 December 1996. FAZC 7581 and 7645, collected by F. Andreone and $\mathrm{J}_{*}$ E. Randrianirina at Masoala (Campsite 2) on 28 November 1998; FAZC 7711, 7796, $7840,7858,7859,7905,7910$, collected by F. Andreone and J. E. Randrianirina at Masoala (Campsite 3) on 2-9 December 1998. ZFMK 57437-57438, same collectors and collecting date as holotype; ZFMK 59897 (cleared and stained specimen), collected by F. Glaw and O. Ramilison at the Marojejy Massif, Campsite 1, on 21-23 February 1995. ZFMK 59929 (cleared and stained specimen), collected by F. Glaw and 0 . Ramilison at the Marojejy Massif (Campsite 3) on 25-26 February 1995; ZFMK 59930-59931, collected by F. Glaw and O. Ramilison at the Marojejy Massif (Campsite 1) on 22 February 1995.

Diagnosis. - A member of the genus Mantidactylus based on the absence of nuptial pads and presence of femoral glands in males. Assigned to the subgenus Laurentomantis based on the moderately, irregularly granular dorsum, the single subgular vocal sac, absence of foot webbing, and completely connected lateral metatarsalia. Distinguished from all other Laurentomantis by presence of a light brown to orange vertebral stripe on the posterior dorsum. Further distinguished from $M$. horridus by smaller body size (male SVL $22-24 \mathrm{~mm}$ vs. 26$28 \mathrm{~mm}$; female SVL $24-27 \mathrm{~mm}$ vs. $35 \mathrm{~mm}$ ), lower note duration (440-1266 ms vs. $1271-2521 \mathrm{~ms}$ ) and higher pulse repetition rate $(29-40 / \mathrm{s}$ vs. $13 / \mathrm{s})$ in advertisement calls; from $M$. ventrimaculatus by absence of regular light marbling (blueish in life) on the venter, and by a longer note duration in advertisement calls (440-1266 ms vs. $407-55 \mathrm{~ms}$ ).

Most similar (and probably closely related) to $M$. malagasius from which it differs by absence of reddish color on hindlimbs (versus red color on posterior and ventral surface of femur in life), largely uniformly dark and smooth ventral surface (versus light surface with dark markings, and granular texture with white-stippled granules), and presence (vs. absence) of a light vertebral stripe on the posterior dorsum. A further difference between both species is found in head width (U-test of ratio HW/ SVL, $\mathrm{P}<0.001 ; \mathrm{P}<0.005$ considering males only), although some range overlap in this character exists. On the Masoala peninsula, the two species come into close contact and even syntopy: while only $M$. striatus was collected at Ilampy and only M. malagasius at Andranobe, at Campsite 2 both species were captured.

Description of holotype. - Adult male, SVL 23.8 $\mathrm{mm}$. For measurements, see Table I. Body slender; head longer than wide, slightly wider than body; snout rounded in dorsal and lateral views; nostrils directed laterally, slightly protuberant, much nearer to tip of snout than to eye; canthus rostralis indistinct, concave; loreal region concave; tympanum small, distinct on left side of head, indistinct on right side, rounded, $42 \%$ of eye diameter; supratympanic fold very indistinct and rather irregular, not clearly curyed; tongue ovoid, distinctly bifid posteriorly; vomerine teeth not visible on the buccal roof, but present under the mucous skin, choanae small, rounded. Arms slender, subarticular tubercles single; two outer, and one inner metacarpal tubercles present; fingers without webbing; relative length of fingers $1<2<4<3$, finger 2 distinctly shorter than finger 4 , only slightly shorter than finger 1; finger disks distinctly enlarged; nuptial pads absent. Hindlimbs slender; tibiotarsal articulation reaches between eye and nostril; lateral metatarsalia connected; inner metatarsal tubercle distinct, outer metatarsal tubercle present; only traces of webbing between toes; relative toe length $1<2<5<$ $3<4$, toe 3 distinctly longer than toe 5 . Skin on the upper surface coarsely granular; granules are arranged asymmetrically except for the anterior back and head regions, where some symmetrical larger tubercles and short ridges are present; a number of granules also above the eyes; no distinct enlarged tubercles in the cloacal region; ventral skin smooth. Femoral glands very distinct and prominent. On the right femur, in internal view (after reflection of skin), four large granules are visible, three of which are arranged symmetrically, apparently encircling a weakly marked external central depression. Tibial glands absent. The folded vocal sac marks two distinct longitudinal lateral folds on the posterior throat. 
After six years in preservative, dorsal coloration is uniformly greyish brown, with some darker coloration bordering the dorsal tubercles and granules. The limbs are light brown with distinct dark brown crossbands ( 3 on femur, 3 on tibia, 6-7 on tarsus and foot, 1-2 on humerus, 6-7 on radius and hand). A short ( $3.5 \mathrm{~mm}$ ) beige vertebral stripe starts on the posterior back and ends at the cloaca. Lower lip with indistinct dark and light crossbands. Ventrally uniformly greyish brown. with a few small light spots on chest.

Variation. - The vertebral stripe on the posterior dorsum can be very short as in the holotype, or run along the whole posterior half of the dorsum (e.g. ZFMK 59931, stripe length $12.5 \mathrm{~mm}$ ). It is absent in only a single specimen (MRSN A1937.2) examined. Limb crossbands are 2-4 on femur, 3-4 on tibia, 6-8 on tarsus and foot, 1-2 on humerus, 7-8 radius and hand. Indistinct brown patches are generally present behind the forelimb insertion and in the inguinal region. ZFMK 59930 is exceptionally light colored but agrees in pattern. The ventral ground color is always a diffuse and uniform greyish brown. In the female ZFMK 59931, the throat is of a darker brown shade than the venter. A number of white markings can be present on the chest and on the throat along the lower lip. The hindlimbs are ventrally uniformly diffuse greybrown. Dorsum coarsely granular, the granules generally not forming ridges (the holotype showing an exceptional state). The belly skin is smooth in all specimens. The femoral glands measure between $3.8 \times 1.8 \mathrm{~mm}$ (FAZC 10378) and $4.8 \times 2.1$ mm (MRSN A1938). They consist of 3 (FAZC $7905)$ to 5-6 granules per gland (MRSN A1938). Granule diameter is $0.9-1.2 \mathrm{~mm}$.

No significant sexual dimorphism in relative tympanum size was detected, but the inner metatarsal tubercle was significantly higher in males (U-test, $\mathrm{P}<0.005$ ), and possibly had also a tendency of being larger in males (U-test, $\mathrm{P}=0.09$ ). Mean male size was $92 \%$ of mean female size.

In life, the color was rather similar to that in preservative. The iris was reddish in its upper part, brown in its lower part. The vertebral stripe was generally orange. The ventral side was dark to light grey, without any trace of red or reddish color.
Distribution. -Known from (1) the Marojejy Massif, (2) Tsararano, (3) Masoala (Campsite 2), (4) Ilampy (Fig. 3). Known altitudinal range 300-700 m.

Natural history. - At Marojejy, calling males were observed at night in the vegetation $5-50 \mathrm{~cm}$ around the ground. All specimens at this locality were found along small brooks, at a maximum distance of $5 \mathrm{~m}$ from the water. FAZC 10313 contained two very large unpigmented oocytes (diameter $4 \mathrm{~mm}$ ) and two smaller unpigmented oocytes (diameter $3 \mathrm{~mm}$ ).

Calls. - Recorded at Marojejy. Series of unharmonious notes (Fig. 4c). Note duration was 440$1266 \mathrm{~ms}(823 \pm 324 \mathrm{~ms}, \mathrm{n}=14)$. Duration of intervals between notes was $162-432 \mathrm{~ms}(238 \pm 72 \mathrm{~ms}, \mathrm{n}=13)$. Number of pulses per note was 15-39 $(28 \pm 9, n=14)$. Intervals between pulses lasted 21-23 ms $(n=5)$. Pulse repetition rate was $29-40(35 \pm 4, n=14)$ pulses per note. Frequency was 3000-4500 Hz. Exceptionally, a very long note type (duration ca. 2000 ms, consisting of 75 pulses) was heard.

Key to species of Laurentomantis (see also table II)

(1a) Larger species; male SVL 26-28 mm, female SVL up to $35 \mathrm{~mm}$. Hindlimb mostly short; when adpressed along body, tibiotarsal articulation reaches at most nostril. Pulse repetition rate in notes of advertisement calls low (13/s), note duration long (1.2-2.5 s).... Mantidactylus (Laurentomantis) horridus (1b) Smaller species; male SVL up to $25 \mathrm{~mm}$, female SVL up to $29 \mathrm{~mm}$. Hindlimb mostly long; when adpressed along body, tibio tarsal articulation reaches at least nostril, often snout tip or beyond. Pulse repetition rate in notes of advertisement calls higher $(18-40 / \mathrm{s})$, note duration mostly shorter $(0.4-1.5 \mathrm{~s})$......

(2a) Color in life reddish brown dorsally, dark with blue marbling ventrally. Notes of advertisement calls short (0.4-0.5 s). Mantidactylus (Laurentomantis) ventrimaculatus (2b) Color in life without reddish brown tone dorsally, and without blue marbling ventrally. Notes of advertisement calls generally long (0.4-2.5 s).

(3a) Ventral surface of hindlimbs in life with bright red color. No vertebral stripe. Ventrally with irregular dark/light marbling. Ventral skin slightly gramular, granules marked with small white spots. Head generally about as wide as long.

Mantidactylus (Laurentomantis) malagasius

(3b) Ventral surface of hindlimbs without red color. Posterior back with beige-orange vertebral stripe. Ventrally uniformly 


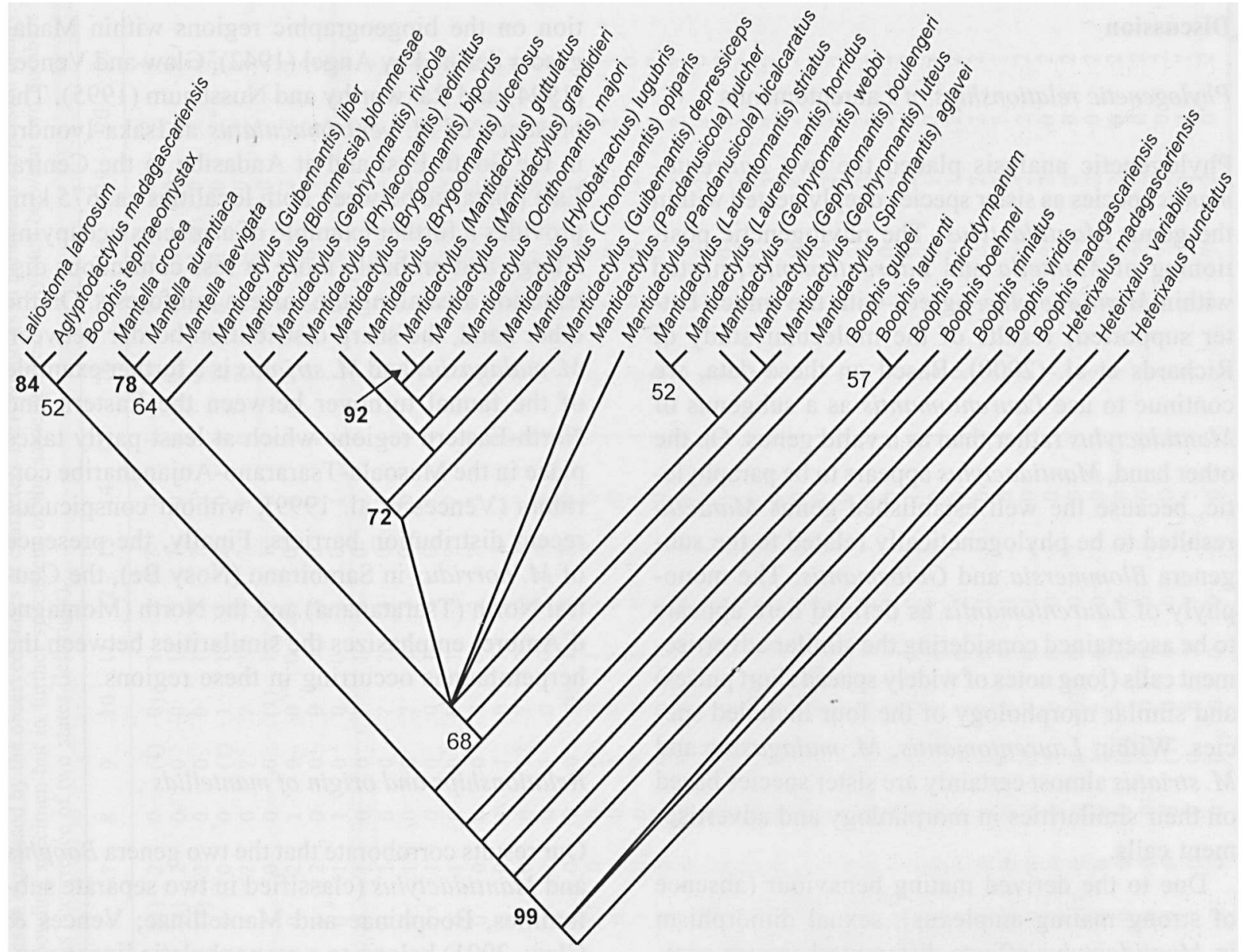

Fig. 6. Maximum parsimony cladogram of a phylogenetic analysis of 34 Malagasy anuran species based on the 54 characters listed in Appendix 1. The tree is a strict consensus of 12 equally most parsimonious trees; 324 steps, consistency index 0.364 . Species of Heterixalus were used as outgroup. Numbers are bootstrap values in percent ( 2000 replications; values below $50 \%$ not shown).

dark grey, sometimes with few light markings. Ventral skin smooth. Head generally slightly longer than wide. Mantidactylus (Laurentomantis) striatus sp. $\mathrm{n}$.

\section{Phylogenetic analysis}

We analysed a total of 54 osteological, morphological, etho-ecological and karyological characters as listed in Appendix 1. Osteological data are based on cleared and stained specimens listed in Table III, and on informations published previously (Glaw et al., 1998; Vences et al., 1998). Non-osteological data were taken from the information summarized in Glaw et al. (1998) and Glaw and Vences (1994). Three species of Heterixalus (family Hyperoliidae) were used as outgroup.
The maximum parsimony analysis (Fig. 6) failed to place Boophis as monophylum: all Boophis species were paraphyletically arranged along the lineage leading to Mantidactylus and Mantella. Mantidactylus and Mantella together formed a monophyletic group, the two Laurentomantis included were sister taxa nested within Mantidactylus. A cluster of three species of the subgenus Gephyromantis were the sister group of Laurentomantis. Mantella was also nested within Mantidactylus, with a species of the subgenus Guibemantis (M. liber) as sister group. Laliostoma and Aglyptodactylus were sister taxa. Bootstrap support for most groupings was low, indicating their relatively low reliability. 


\section{Discussion}

\section{Phylogenetic relationships of Laurentomantis}

Phylogenetic analysis placed the two Laurentomantis species as sister species deeply nested within the genus Mantidactylus. The phylogenetic positioning of Mantella and Laurentomantis, nested within Mantidactylus, agrees with the (much better supported) results of the molecular study of Ríchards et al. (2000). Based on these data, we continue to use Laurentomantis as a subgenus of Mantidactylus rather than as a valid genus. On the other hand, Mantidactylus appears to be paraphyletic, because the well established genus Mantella resulted to be phylogenetically related to the subgenera Blommersia and Guibemantis. The monophyly of Laurentomantis as defined here appears to be ascertained considering the similar advertisement calls (long notes of widely spaced short pulses) and similar morphology of the four included species. Within Laurentomantis, M. malagasius and M. striatus almost certainly are sister species based on their similarities in morphology and advertisement calls.

Due to the derived mating behaviour (absence of strong mating amplexus), sexual dimorphism in Mantidactylus affects different character complexes in comparison to most other frogs. As in other Mantidactylus, males of the subgenus Laurentomantis lack nuptial pads. Sexual size dimorphism appears to be rather pronounced in at least two species, $M$. horridus and $M$. ventrimaculatus, in which male size is $76-82 \%$ of female size. In contrast, it is faint in M. malagasius and M. striałus (male size $>90 \%$ of female size). At least in $M$. striatus, males have a (slightly) larger inner metatarsal tubercle, a state shared with species of the subgenera Phylacomantis and Gephyromantis; a survey of this character in more subgenera of Mantidactylus is necessary to assess its phylogenetic value.

\section{Biogeography}

The distribution patterns of the four Laurentomantis species as revised herein provide some informa- tion on the biogeographic regions within Madagascar defined by Angel (1942), Glaw and Vences (1994) and Raxworthy and Nussbaum (1995). The presence of $M$. ventrimaculatus at Isaka-Ivondro in the South-East and at Andasibe in the Central East (distance between both localities ca. $675 \mathrm{~km}$ ) provides a further example of a species occupying a large and probably more or less continuous distribution area along the eastern rainforests. On the other hand, the sharp distribution border between M. malagasius and M. striatus is a further example of the faunal turnover between the Eastern and North-Eastern regions which at least partly takes place in the Masoala-Tsararano-Anjanaharibe corridors (Vences et al. 1999), without conspicuous recent distribution barriers. Finally, the presence of M. horridus in Sambirano (Nosy Be), the Central North (Tsaratanana) and the North (Montagne d'Ambre) emphasizes the similarities between the herpetofaunas occurring in these regions.

\section{Relationships and origin of mantellids}

Our results corroborate that the two genera Boophis and Mantidactylus (classified in two separate subfamilies, Boophinae and Mantellinae; Vences \& Glaw, 2001) belong to a monophyletic lineage endemic to Madagascar and adjacent islands (Richards and Moore, 1998; Bossuyt and Milinkovitch, 2000; Vences et al,, 2000) which has been defined as family Mantellidae (Vences and Glaw, 2001). A major difference between the two genera is the apomorphic loss of the anterolateral process of the hyoid plate in most Boophis (Glaw et al., 1998), but this process is present in $B$. tephraeomystax according to the new data presented herein (Tables III and IV). We also ascertained that the number of tarsals, previously used to distinguish both genera (Blommers-Schlösser, 1993; Glaw et al., 1998) is variable within Boophis (a small but distinct third free tarsal in B. tephraeomystax and B. guibei; only two tarsals in the remaining species examined) and possibly also in Mantidactylus (if our observation of only two tarsals in $M$. horridus is not an artifact caused by poor alcian blue staining of the often cartilaginous third tarsal). This also stresses that the value of osteology and morphology to assess 


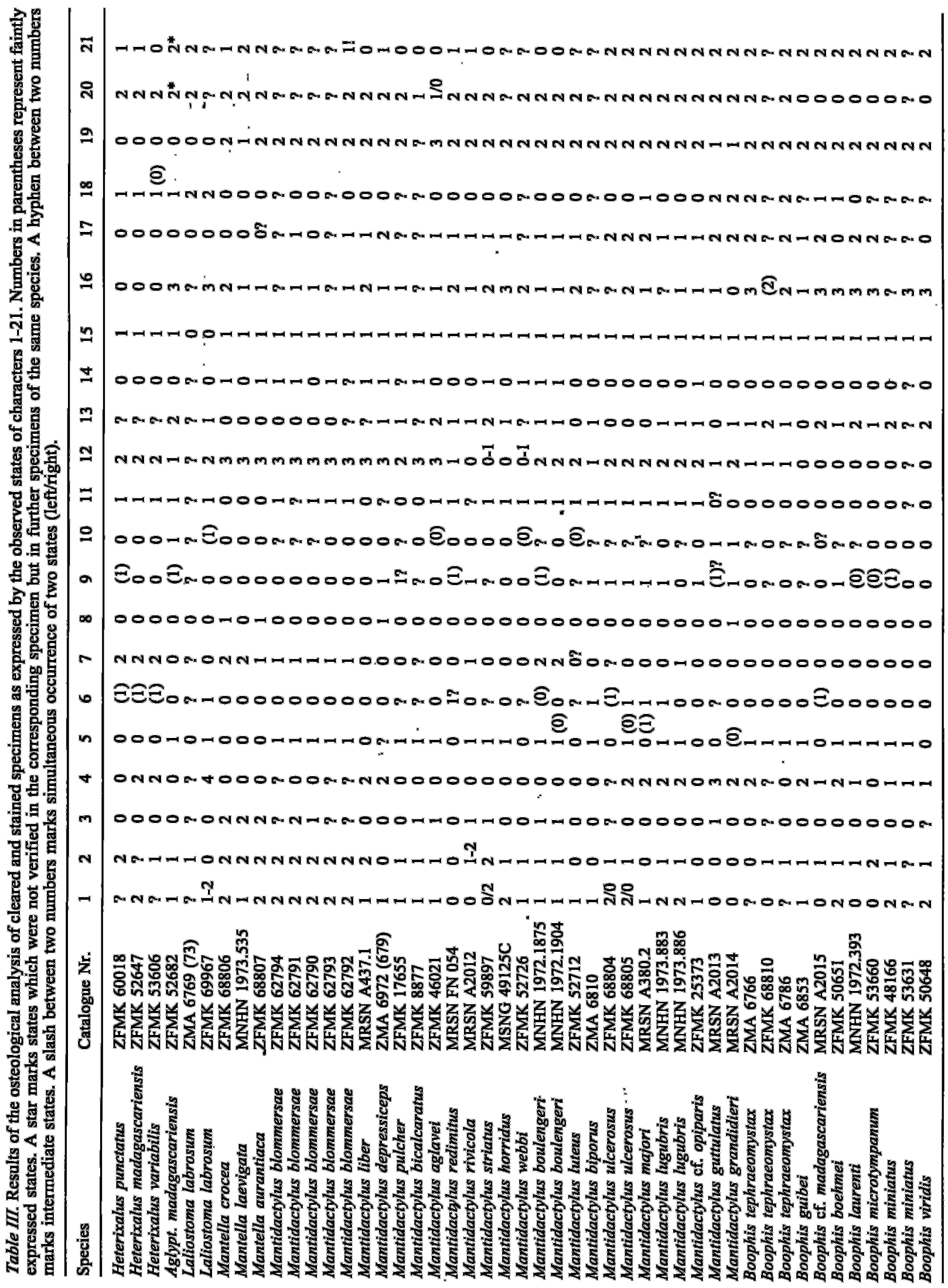




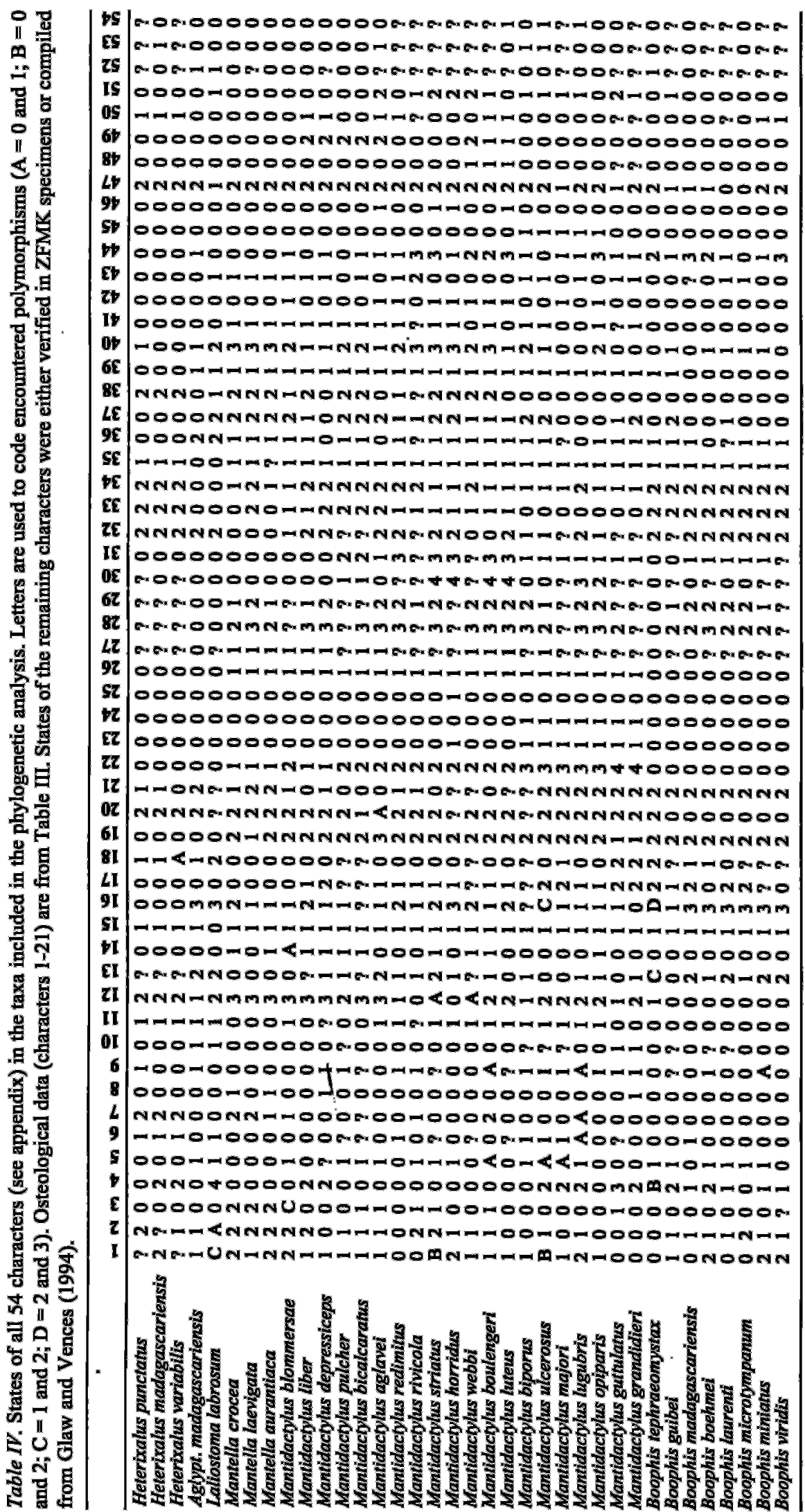


phylogenetic relationships among frogs is limited by the high degree of homoplasy affecting many characters.

Vences et al. (2000), noted that basal relict groups among Malagasy anurans mainly occur in dry western Madagascar, and hypothesized that the ancestors of extant rainforest frogs in Madagascar were adapted to arid conditions. In contrast, specialization to constant humid conditions is probably found in the Mantidactylus species without free-swimming larvae: direct development is known in the subgenus Gephyromantis, and is probable at least in some Laurentomantis based on the data presented in the present paper (large eggs, calling largely independent from water bodies). As no terrestrial Tertiary fossils are known from Madagascar, the classification of the Latest Cretaceous remains as described by Asher and Krause (1998) is of importance to reconstruct the timing of these adaptive radiations into rainforest environments. The main fragments - an atlas and a sacrum - belong to large frogs characterized by a procoelous vertebral column and narrowly separated atlantal cotyles. As mantellids are generally characterized as diplasiocoelous and having widely separated cotyles, Asher and Krause (1998) concluded that the fossils were related to the more basal Pelobatidae (which has no extant representatives in Madagascar and Subsaharan Africa). This conclusion is sound, taking into account the overall archaic Cretaceous fauna of Madagascar (Krause et al., 1997). However, it must be noted that one of the largest extant endemic Malagasy frogs, Mantidactylus guttulatus, is characterized by procoely (Guibé, 1978). According to data presented here, this species and the closely related M. grandidieri, as well as Aglyptodactylus and Laliostoma, also have narrowly separated cotyles. In these species, the space between cotyles is slightly larger than the width of one cotyle, agreeing with the state shown by Asher and Krause (1998) in their fossil specimen FMNH PR-1961. The hypothesis that the remains belong to Mantidactylus, and that mantellids were already present on Madagascar during the Latest Cretaceous, can thus not be ruled out at the present state.

\section{Acknowledgements}

We are indebted to N. Rabibisoa, D. Rakotomalala, O. Ramilíson, F. Ranaivojaona, and J. E. Randrianirina for their help in the field. W. Böhme (Bonn), B. Clarke and C. McCarthy (London), B. van Tuijl (Amsterdam), D. Vallan and K. Grossenbacher (Bern), G. Köhler (Frankfurt), R. Poggi and G. Doria (Genova), and A. Dubois and A. Ohler (Paris) allowed examination and partly dissection of specimens held in their care. W. Böhme additionally allowed the exchange of the holotype of $M_{*}$ striatus to the ZSM. M. Matasconi (Bonn) carried out part of the osteological examinations. We are grateful to the Malagasy authorities for research and export permits. The work of FG and MV was made possible by a cooperation accord between the Departément de Biologie Animale, Université d'Antananarivo and the Zoologisches Forschungsinstitut und Museum A. Koenig, Bonn, and financially supported by the Deutscher Akademischer Austauschdienst (DAAD). The survey work of FA at Masoala was carried out within a project in collaboration with the Parc Botanique et Zoologique de Tsimbazaza (Antananarivo), supported by the Wildlife Conservation Society (WCS) (Antananarivo), and the Museo Regionale di Scienze Naturali (Torino) aimed at monitoring some rainforest areas in northern Madagascar. For their" assistance, he is very grateful to the WCS staff at Antananarivo, especially M. Hatehwell, and to all the people of WCS at Maroantsetra.

\section{References}

Angel F. 1935. Batraciens nouveaux de Madagascar, récoltés par M. R. Catala, Bull. Soc. Zool. France 60: 202-207.

Angel F. 1942. Les lezards de Madagascar. Mem. Academie Malgache 36: 1-139.

Asher RJ, Krause DW. 1998. The first pre-Holocene (Cretaceous) record of Anura from Madagascar. $J$. Vertebrate Paleontology 18: 696-699.

Blommers-Schlösser RMA. 1993. Systematic relationships of the Mantellinae Laurent 1946 (Anura Ranoidea). Ethol. Ecol. Evol. 5: 199-218.

Blommers-Schlösser RMA, Blanc CP. 1991. Amphibiens (première partie). Faune de Madagascar 75 (1): 1-379.

Blommers-Schlösser RMA, Blanc CP. 1993. Amphibiens (deuxième partie), Faune de Madagascar 75 (2): 385-530.

Boettger 0. 1880. Diagnoses Reptilium et Batrachiorum novorum a Carolo Ebenau in insula Nossi-Bé Madagascariensi lectorum. Zool. Anz, 3: 279-283.

Boulenger GA. 1882. Catalogue of the Batrachia Salientia s. Ecaudata in the collection of the British Museum. Addenda. London, Trustees of the British Museum.

Bossuyt F, Milinkovitch MC. 2000. Convergent adaptive radiations in Madagascan and Asian raníd frogs reveal covariation between larval and adult traits. Proc. Natl.Acad. Sci. USA 97: 6585-6590.

Clarke B. 1981. Comparative osteology and evolutionary rela- 
tionships in the African Raninae (Anura Ranidae). Monit. zool. Ital. (N.S.) suppl. 15: 285-331.

Dubois A. 1980. Un nom de replacement pour un genre de ranidés de Madagascar (Amphibiens, Anoures). Bull. Mus. natn. Hist. nat. (4) 2: 349-351.

Dubois A. 1992. Notes sur la classification des Ranidae (Amphibiens Anoures), Bull. mens. Soc. linn. Lyon 61: 305352.

Glaw F, Vences M. 1994. A fieldguide to the amphibians and reptiles of Madagascar. 2 nd edition. Köln: Vences and Glaw Verlag.

Glaw F, Vences M. 2000. Current counts of species diversity and endemism of Malagasy amphibians and reptiles. In: Lourenco WR, Goodman SM (eds.). Diversité et endémisme de Madagascar. Mémoíres de la Société de Bíogéographie, Paris, 243-248.

Glaw F, Vences M, Böhme W. 1998. Systematic revision of the genus Aglyptodactylus Boulenger, 1919 (Amphibia: Ranidae), and analysis of its phylogenetic relationships to other Madagascan ranid genera (Tomopterna, Boophis, Mantidactylus, and Mantella). J. Zool. Syst. Evol. Res. 36: 17-37.

Glaw F, Vences M, Gossmann V. 2000. A new species of Mantidactylus (subgenus Guibemantis) from Madagascar, with a comparative survey of internal femoral gland structure in the genus (Amphibia: Ranidae: Mantellinae). $J$ Nat. Hist. 34: 1135-1154.

Guibé J. 1978. Les batraciens de Madagascar. Bonn. Zool. Monogr. 11: 1-140.

Hofrichter R. 1998 (ed.). Biologie der Amphibien. Augsburg: Naturbuch Verlag.

Krause DW, Hartman JH, Wells NA. 1997. Late Cretaceous vertebrates from Madagascar. Implications for biotic changes in deep time. In: Goodman SM, Patterson BD (eds). Natural change and human impact in Madagascar. Smithsonian Institution Press, Washington and London, 343.

Methuen PA. 1920. Descriptions of a new snake from Transvaal, together with a new diagnosis and key of the genus Xenocalamus, and of some Batrachia from Madagascar. Proc. Zool. Soc. London 25: 349-355.

Methuen PA, Hewitt J. 1913. On a collection of Batrachia from Madagascar made during the year 1911. Ann. Transvaal Musseum (4) 2: 49-64.

Perrier de la Bathie H. 1927. Le Tsaratanana, I"Ankaratra et 1'Andringitra. Mem. Acad. malgache 3: 1-70.

Raxworthy CJ, Nussbaum RA. 1994. A rainforest survey of amphibians, reptiles and small mammals at Montagne d'Ambre, Madagascar, Biol. Conserv. 69; 65-73.

Raxworthy CJ, Nussbaum RA. 1995. Systematics, speciation and biogeography of the dwarf chameleons (Brookesia; Reptilia, Squamata, Chamaeleontidae) of northern Madagascar, J. Zool. Lond. 235: 525-558.

Richards CM, Moore WS. 1998. A molecular phylogenetic study of the Old World Treefrogs, family Rhacophoridae. Herpetol. J. 8: 41-46.
Richards CM, Nussbaum RA, Raxworthy CJ. 2000. Phylogenetic relationships within the Madagascan boophids and mantellids as elucidated by mitochondrial ribosomal genes. African J. Herpetol. 49: 23-32.

Swofford DL. 1998. PAUP*. Phylogenetic Analysis Using Parsimony (* and other methods), Version 4. Sunderland, Massachusets: Sinauer Associates.

Vallan D. 2000. Influence of forest fragmentation on amphibian diversity in the nature reserve of Ambohitantely, highland Madagascar. Biol. Conserv. 96: 31-43.

Vences M, Glaw F. 2001. When molecules claim for taxonomic change: New proposals on the classification of Old World treefrogs. Spixiana 24: 85-92.

Vences M, Glaw F. submitted. Revision of the subgenus Chonomantis (Anura: Ranidae: Mantidactylus) from Madagascar, with description of two new species.

Vences M, Glaw F, Mausfeld P, Böhme W. 1998. Comparative osteology of Malagasy poison frogs of the genus Mantella (Amphibia: Ranidae: Mantellinae), Bonn. zool. Beitr, 48: 205-215.

Vences M, Ziegler T, Visser S, Andreone F, 1999. New data on the zoogeography and genital morphology of the lizards Zonosaurus brygooi Lang and Böhme 1990 and Z. aeneus (Grandidier 1872) from Madagascar (Reptilia Squamata Gerrhosauridae), Tropical Zool. 12: 145-155.

Vences M, Glaw F, Kosuch J, Das I, Veith M. 2000. Polyphyly of Tomopterna (Amphibia: Ranidae) based on sequences of the mitochondrial 16S and 12S rRNA genes, and ecological biogeography of Malagasy relict amphibian groups. In: Lourenco WR, Goodman SM (eds.). Diversité et endémisme a Madagascar. Mémoìres de la Société de Biogéographíe, Paris, 229-242.

Received: 14 May 2001

\section{Appendix: Characters used for analysis}

Character 1. Medial contact of nasals: $(0)$ close medial contact between nasals, (1) nasals narrowly separated medially, (2) nasals widely separated medially.

Character 2. Squamosal: (0) zygomatic process of squamosal of similar length or longer than posterior (otic) process, (1) zygomatic process of squamosal slightly shorter than posterior (otic) process, (2) zygomatic process of squamosal much shorter than posterior (otic) process.

Character 3. Maxilla preorbital process of pars fascialis: $(0)$ a distinct triangular or elongate process at the level of palatines, mostly directed posteriorly, (1) a small distinct triangular or elongate process at the level of palatines, (2) process absent or very reduced.

Character 4. Maxilla preorbital process, anterior part: (0) maxilla anteriorly not especially high, (1) maxilla anteriorly with a distinct process, separated from preorbital process by a deep notch, (2) maxilla anteriorly high, with a similar height to the preorbital process which is protruding still higher, (3) maxilla 
anteriorly high, continuing to the level of the palatines, without additional preorbital process, (4) maxilla anteriorly very high, with two protruding processes, an anterior one and a second one at the level of the palatines.

Character 5. Anterior end of maxilla: (0) concave, (1) convex. Character 6. Palatínes: (0) reaching medially to vomerine odontophore, (1) reaching medially further than odontophore. Character 7. Vomerine odontophore and vomerine teeth: (0) teeth and odontophore present, (1) teeth absent or rudimentary, odontophore present but very thin, (2) teeth and odontophore absent.

Character 8. Maxillary teeth: (0) present, (1) absent.

Character 9. Parasphenoid: (0) not reaching palatines anteriorly, (1) reaching palatines anteriorly.

Character 10. Separation of atlantal cotyles: (0) wide (distance between cotyles larger than their width), (1) narrow (distance between cotyles smaller than their width).

Character 11. Vertebral column: (0) procoelous, (1) díplasiocoelous.

Character 12. Base of omosternum: (0) unforked, (1) slightly forked, the greatest space between the arms is less than half the width of one arm, (2) moderately forked, the greatest space between the arms is once to twice the width of one arm, (3) broadly forked, the greatest space between the arms is two to four times the with of one arm.

Character 13. Relative omosternum length: (0) longer than sternum, (1) of same length as sternum, (2) shorter than sternum. Character 14. Base of sternum: (0) unforked, (1) forked.

Character 15 . Intercalary element: (0) absent, (1) present. Character 16. Free distal tarsals: (0) three free tarsals, the third tarsal being rather large, (1) three free tarsals, the third tarsal being small, (2) three free tarsals, the third tarsal being extremely small, (3) two free tarsals.

Character 17. Number of prehallux elements arranged in one row: (0) two, (1) three, (2) four.

Character 18. Additional prehallux element, leading to an axeshape: (0) absent, (1) present, very small, (2) present, distinct. Character 19. Terminal phalanges: (0) not bilobed nor forked (more or less knob-like), (1) very slightly bilobed, (2) distinetly bilobed or slightly Y-shaped, (3) distinetly Y-shaped.

Character 20. Anterolateral process of hyoid plate: (0) absent, (1) rudimentary, (2) present and distinct.

Character 21. Posterolateral process of hyoid plate: (0) absent, (1) rudimentary, (2) present and distinct.

Character 22. Femoral glands in males (according to Glaw et al. 2000): (0) absent, (1) gland type 1, (2) gland type 2, (3) gland type 3, (4) gland type 4 .

Character 23. Enlarged distal femoral gland section with external central median depression in males: (0) absent, (1) present.

Character 24. Femoral glands in females: (0) absent, (1) present as rudiments.

Character 25. Tibial glands (0) absent, (1) present in males (present or absent in females).

Character 26. Nuptial pads and reproductive behaviour: (0). nuptial pads present (as far as known, strong mating amplexus and release calls present), (1) nuptial pads absent (as far as known, strong mating amplexus and release calls absent). Character 27. Egg deposition: (0) aquatic, (1) terrestrial. Character 28. Maximum number of eggs laid by one female: (0) $>1000$, (1) 500-1000, (2) 100-500, (3) <100.

Character 29. Maximum diameter of eggs or mature oocytes in gravid females: (0) 1-2 mm, (1) larger than $2 \mathrm{~mm}$.

Character 30. Tadpole morphology: (0) generalized tadpole, (1) specialized phytotelmous tadpole, (2) funnel-mouth tadpole, (3) specialized tadpole with probably filtering mouthparts, (4) (probably) direct development.

Character 31. Larval development in: (0) free lentic water, (1) free lotic water, (2) phytotelmes or tree holes, (3) (probably) outside free water.

Character 32. Calling activity: (0) mainly diurnal, (1) diurnal and nocturnal, (2) mainly nocturnal.

Character 33. Habits: (0) terrestrial/semiaquatic, (1) scansorial, (2) arboreal.

Character 34. Circummarginal groove ventrally on finger and toe pads: (0) absent or incomplete, (1) complete.

Character 35. Fingertips: (0) not enlarged, (1) slightly enlarged, (2) distinctly enlarged.

Character 36. Relative finger length: $(0)$ second finger longer than first finger, (1) first and second finger of similar length, (2) first finger longer than second finger.

Character 37. Relative toe length: (0) fifth toe longer than third toe, (1) fifth and third toe of similar length, (2) fifth toe shorter than third toe.

Character 38. Lateral metatarsalia: (0) separated by webbing, (1) partly connected, (2) connected.

Character 39 . Webbing between fingers: $(0)$ present and distinct, (1) absent or almost absent.

Character 40. Inner foot webbing at fourth toe: (0) 0-1 phalanges free of web, (1) 1.5-2 phalanges free of web, (2) 2.5-3 phalanges free of web, (3) no foot webbing.

Character 41. Outer metatarsal tubercle: (0) absent, (1) present.

Character 42. Outer metacarpal tubercles: $(0)$ single or indistinct, (1) double and prominent.

Character 43. Relative foot length: $(0)$ foot longer than tibia, (1) foot and tibia more or less of same length, (2) foot shorter than tibia.

Character 44. Relative hindlimb length: tibiotarsal articulation mostly reaches: (0) between tympanum and eye, (1) beyond eye, not beyond nostril, (2) beyond nostril, not beyond snout tip, (3) beyond snout tip.

Character 45. Sexual dimorphism in relative tympanum size: (0) tympanum of similar size in males and females, (1) tympanum distinctly larger in males than in females.

Character 46. Dermal spines or prominent granules above eyes: (0) absent, (1) present.

Character 47. Position of nostrils: $(0)$ nearer to eye than to snout tip, (1) midway between eye and snout tip, (2) nearer to snout tip than to eye.

Character 48. Vocal sac: (0) single or slightly bilobed subgular, (1) paired subgular.

Character 49. Vocal sac color: (0) no conspicuous color (not 
clearly differing from general ventral coloration), (1) black, (2) white.

Character 50. Vocal sac inflation: $(0)$ vocal sac slightly distensible, (1) vocal sac largely distensible.

Character 51. Dorsal skin: (0) smooth, (1) slightly granular, (2) moderately to coarsely granular.
Character 52. Cellular DNA content: (0) around modal value, (1) distinetly lower than modal value.

Character 53. Karyotype: (0) $2 n=26$ chromosomes, (1) $2 n=24$ chromosomes.

Character 54. Acrocentric chromosomes: (0) absent, (1) present. 